\title{
Banalność pragmatyzmu i piękno amerykańskiej nadziei
}

\author{
DOI $10.35757 /$ CIV.2013.15.14
}

Richard Rorty: Filozofia a nadzieja na lepsze społeczeństwo, opracowanie i przedmowa J. Grygieńć, przekład J. Grygieńć, S. Tokariew, Wydawnictwo Naukowe Uniwersytetu Mikołaja Kopernika, Toruń 2013, ss. 344.

Richard Rorty to postać, której osobom zainteresowanym współczesna amerykańska filozofia polityki nie trzeba przedstawiać. To on jest (oprócz Hilary'ego Putnama) odpowiedzialny za nagły powrót zainteresowania w Ameryce rodzima tradycja filozoficzna, czyli zmarginalizowanym od czasów śmierci Johna Deweya pragmatyzmem (tym razem $z$ przedrostkiem „neo”).

Filozofia a nadzieja na lepsze społeczeństwo, wydana po polsku trzynaście lat po amerykańskim debiucie, stanowi najbardziej przystępną, a zarazem najbardziej romantyczną i literacką spośród jego ksiażek. W przeciwieństwie do innych dzieł neopragmatysty, kierowanych przede wszystkim do społeczności akademickiej, to napisane jest dla szerokiego, lecz też wykształconego kręgu odbiorców amerykańskich. Spośród ponad dwudziestu zamieszczonych w książce wykładów, artykułów, esejów i polemik blisko połowa była wcześniej dostępna w języku polskim, choć rozproszona po różnych wydawnictwach. Tym razem w celu zachowania spójności językowej otrzymały one nowe przekłady. Całość poprzedza bardzo przystępna, kilkunastostronicowa przedmowa Janusza Grygieńcia, umożliwiająca zapoznanie się z najistotniejszymi tezami neopragmatysty, jego uniwersum pojęciowym i najważniejszymi nieporozumieniami narosłymi wokół tej filozofii. Po uważnym przeczytaniu tej przedmowy czytelnik, który miał już wcześniej pe- 
wien kontakt ze współczesną filozofia, $z$ pewnością będzie w stanie $z$ lektury Rorty'ego - piszacego bardzo barwnie, zajmująco, wręcz uwodzicielsko - czerpać przyjemność estetyczna i intelektualna.

Książka jest podzielona na pięć bardzo różniących się objętością części oraz opatrzona wstępem i wprowadzeniem zatytułowanym Relatywizm: odkrywanie $i$ tworzenie, opublikowanym już wcześniej jako rozdział w zbiorze Habermas, Rorty, Kołakowski. Stan filozofii współczesnej (Instytut Filozofii i Socjologii PAN, Warszawa 1996).

Część pierwsza, zatytułowana Autobiografia, zawiera doskonale już znany polskiemu czytelnikowi tekst autobiograficzny Trocki i dzikie storczyki. Część druga - Nadzieja zamiast wiedzy - obejmuje polemiki Rorty'ego $z$ tradycyjna metafizyka i epistemologia; $z$ ich słownictwem i antynomiami odziedziczonymi po starożytnych Grekach. Część trzecia - Pewne zastosowania pragmatyzmu - ukazuje, jakie pożytki może przynieść pragmatyzm na polu jurysprudencji, krytyki literackiej, etyki, nauki oraz w debatach o miejscu i roli religii we współczesnym społeczeństwie amerykańskim. Część czwarta - Polityka - prezentuje refleksje dotyczące pożądanego, zdaniem autora, stosunku lewicy do Marksa i marksizmu, a także kwestię aktualności idei socjalizmu, oraz wskazuje na zadania czekające liberałów i progresywistów. Część piąta - Ameryka - przedstawia, w jaki sposób dziedzictwo amerykańskiej lewicy mogłoby pełnić funkcję busoli wiodącej ku lepszej przyszłości.

Rorty we wstępie tak pisze o swoim dziele: „Większość $z$ tego, co napisałem w przeciagu ostatniej dekady to próby powiąania moich nadziei na lepsze społeczeństwo - społeczeństwo globalne, kosmopolityczne, egalitarne, bezklasowe i bezkastowe $z$ moja wrogością wobec platonizmu" (s. 25). Przez platonizm rozumie Rorty między innymi następujące dualizmy: umysł-materia, podmiot-przedmiot, wytworzone-znajdowane, rzeczywistość-pozór, esencja-przypadłość, wiara-wiedza, fakt-wartość, zmysłowe-intelektualne, roztropne-moralne. Według neopragmatysty problemy epistemologiczne odziedziczone po Platonie, Arystotelesie, Kar- 
tezjuszu i Kancie można unieważnić, porzucając język, w który są one uwikłane. Rorty chce, byśmy przestali mniemać, że „najbardziej dystynktywną i chwalebną zdolnością rodzaju ludzkiego jest poznanie rzeczy takimi jakie sa, przedarcie się przez pozór do rzeczywistości” (s. 26). Pisze: „Moim kandydatem do roli najbardziej dystynktywnej i chwalebnej zdolności ludzkiej jest zdolność ufania innym i współpracy, zwłaszcza w imię lepszego jutra” (s. 26). Najbardziej zaś obiecujacym i udanym projektem politycznym jest, zdaniem autora Przygodności, ironii i solidarności, meliorystyczny, socjaldemokratyczny projekt Johna Deweya zaprowadzenia w Ameryce społeczeństwa bezklasowego i egalitarnego. Rorty twierdzi, iż „porzucenie starych dualizmów może skutkować przypisaniem temu projektowi równie ważnego miejsca w naszym życiu intelektualnym, co to zajmowane przezeń w naszym życiu politycznym”. I dodaje: „Moim celem jest deprecjacja poszukiwania wiedzy $z$ poziomu celu $\mathrm{w}$ sobie do jednego $z$ wielu środków uszczęśliwiania ludzi” (s. 27).

Rorty chce, by amerykańscy intelektualiści zajęli się propagowaniem solidarności międzyludzkiej i praktyk charakterystycznych dla zachodniego demokratycznego państwa dobrobytu. Odrzucenie koncepcji niezmiennej natury ludzkiej, metafizyki praw człowieka czy pojęcia racjonalności ma sprzyjać współpracy wszystkich liberałów (ludzi przekonanych, że najgorszą rzeczą na świecie jest okrucieństwo, ból, cierpienie i upokorzenie), aktywizmowi politycznemu i likwidacji filozoficznego pustosłowia. Tym bardziej że poszukiwanie jednej, ponadczasowej, obejmującej całość i dostępnej człowiekowi wiedzy, teorii jest próbą ucieczki od świata i dyskusji $z$ innymi.

$Z$ osiagnięć klasyków pragmatyzmu korzysta Rorty, jak sam przyznaje, wybiórczo. Od Jamesa przejmuje przekonanie, iż prawda jest tym, co korzystne w sferze naszych czynów, prawdziwość zaś to określenie wszelkich przekonań, co do których praktyka dowiodła, że warto przy nich obstawać i w nie wierzyć. Od Peirce’a zapożycza traktowanie przekonań jako nawyków działania, nie zaś reprezentacji oraz krytykę prawdy absolutnej i obiektywnej. 
Rorty zaprzecza, jakoby istniały silne więzi między przekonaniami filozoficznymi a politycznymi. Demokratyzm Deweya nie przemawia na rzecz jego pragmatyzmu, a nazizm Heideggera na niekorzyść jego krytyki rozróżnienia między rzeczywistością a pozorem. Podobnie nie ma jednoznacznych zależności między wrażliwością moralna a zdolnościa do stworzenia interesującej filozoficznej narracji czy dzieła sztuki. Autor podkreśla: „W szczególności nie istnieje żaden powód, dla którego faszysta nie mógłby być pragmatysta, jeśli pod tym ostatnim pojęciem rozumiemy większość poglądów Deweya na naturę prawdy, wiedzy, racjonalności i moralności” (s. 73).

Rorty traktuje teksty, teorie filozoficzne jak skrzynki $z$ narzędziami, z których czerpie w zależności od swoich potrzeb. W tekście Heidegger $i$ nazizm - napisanym, jak sam stwierdza, „dla frajdy” - stwarza alternatywna biografię autora Bycia i czasu. W tej fikcyjnej biografii Heidegger zakochuje się w Żydówce, staje się antynazista i emigruje - najpierw do Szwajcarii, a później do Ameryki. Pogarda Heideggera dla Stanów Zjednoczonych jako „kraju bez kultury", nieudanej realizacji nadziei oświecenia nie przeszkadza mu jednak w wygłoszeniu porywajacych antynazistowskich audycji, które „pozwalaja mu zaspokoić potrzebe przybrania heroicznej pozy przed masami ludzi - potrzebę, którą w innych warunkach zaspokoiłaby przemowa rektorska" (s. 253).

W alternatywnym świecie sedno myśli Heideggera, dążącej do wykroczenia poza zastane tradycje filozoficzne, pozostałoby takie samo, ale wydźwięk jego dzieł, dzięki subtelnym przesunięciom znaczeniowym, będacych rezultatem przypadkowych okoliczności byłby inny. „W tamtym świecie jego Wprowadzenie do metafizyki zawiera jednak utożsamienie ruchu narodowosocjalistycznego $z$ bezmyślnym nihilizmem nowoczesnej technologii, a także uwage o tym, że Hitler sprowadza Niemcy do metafizycznego poziomu Ameryki i Rosji" (s. 254) - pisze o mędrcu ze Szwarcwaldu Rorty.

Neopragmatysta stroni od prostej ideologizacji filozofii. Filozofia jest dla niego jednym $z$ działów kultury, podobnym do polityki 
czy literatury, a filozof - przede wszystkim spadkobierca pewnej tradycji, a nie następca kapłana czy prawodawcy. Pokpiwa $z$ metodolatrii i wielkich narracji charakterystycznych dla filozofii kontynentalnej. Przyświeca mu cel iście feuerbachowski, terapeutyczny - chce przywrócić czytelnikom wiarę $\mathrm{w}$ ich własne siły. W tym celu zakreśla zadania filozofii, aby w ich realizacji mogli uczestniczyć nie tylko filozofowie, ale także ci wszyscy, którym zależy na przyszłości Ameryki.

Powiada, że nie jest możliwe ujęcie w jednej wizji idiosynkratycznych, prywatnych miłości i upodobań $z$ obowiązkami wobec bliźnich. Nie możemy liczyć na to, że kiedykolwiek uda nam się wejść między język a świat. Nie powinniśmy mieć nadziei na to, że znajdziemy punkt ponad założeniami, poza czasem i przestrzenia. Nie uda nam się uzasadnić przed wszystkimi, bez względu na kontekst, swoich podstawowych przekonań. Nie istnieje niezawodny, racjonalny sposób na uczynienie $z$ nazisty współczującego liberała.

Rorty chce nam zasugerować, że „ludzie sa skazani na własne siły i żadna nadnaturalna światłość nie przywiedzie ich ku Prawdzie”. Dodaje: „Oświecenie zastapiło oczywiście ideę takiej nadnaturalnej światłości idea quasi-boskiej zdolności zwanej "rozumem». Tę właśnie ideę atakuja [jako metafizyczna - przyp. T.S.] amerykańscy pragmatyści [...]" (s. 43). Demokracja i nieprzerwane toczenie się w niej dyskusji światopoglądowych sa dla autora Przygodności, ironii $i$ solidarności filozoficznym i politycznym sacrum.

Tytuł znanego zbioru wywiadów z Rortym - Zatroszczmy sie o wolność, a prawda zatroszczy się o siebie sama ${ }^{1}$ - można uznać za swoiste motto twórczości amerykańskiego filozofa. Filozof wyraźnie zaznacza, że w sporach politycznych lub światopoglądowych nikt nie powinien mieć ostatniego zdania, prawa do jednoznacznego zakończenia dyskusji, czy to na mocy autorytetu, stosowanej metodologii, wyznawanej ideologii, religii, czy zajmowanej pozycji zawodowej.

1 Take Care of Freedom and Truth Will Take Care of Itself. Interviews with Richard Rorty, red. i wprowadzenie F. Manetta, Stanford University Press, Redwood City, CA 2006. 
W dziedzinie epistemologii i zarazem ontologii Rorty przyjmuje antyesencjalizm oraz tezę o względności opisu $z$ uwagi na potrzeby i cele. Nie jesteśmy bowiem w stanie stwierdzić, czy bardziej prawidłowym opisem żyrafy jest opis jej jako góry mięsa, dokonany przez paleolitycznego myśliwego, czy też zbiorowiska atomów, jak opisałby ja fizyk. Nie jesteśmy też w stanie określić, czy rzeczy w otaczającej nas rzeczywistości są konstruowane, czy odnajdywane. Oczywiście Rorty zdaje sobie sprawę, że żyrafy istniałyby i bez człowieka, konta bankowe natomiast nie. Niemniej sposób, w jaki „wykrawamy” obiekty z otaczającej nas rzeczywistości stanowi już funkcję potrzeb. Pozytywnym stanowiskiem neopragmatysty jest też panrelacjonizm, tj. teza, iż opis przedmiotu to jednocześnie opis relacji łaczaccych go $z$ innymi. Rorty prezentuje tę tezę na przykładzie liczb naturalnych. Liczb nie da się traktować esencjalnie - każdy opis liczby jest równorzędny i stanowi wiązkę relacji do innych liczb. Nie można stwierdzić, czy bardziej prawidłowy opis liczby 17 to pierwiastek z 289 czy też różnica 25 i 8.

Zaleta wyżej przedstawionych stanowisk, według Rorty'ego, polega na tym, że nie uprzywilejowuja reprezentantów żadnej dziedziny kultury czy też nauki w toczących się dyskusjach. Tym bardziej że teoria jest dla niego zawsze tożsama $z$ planem działania Jak pisze: „Nie możemy uczynić prawdy celem dociekań. Taki cel stanowi porozumienie w kwestii sposobu działania, konsensus co do wartościowości celów i stosowności środków ich realizacji. Dociekanie nie skutkujące koordynacja zachowań nie jest dociekaniem, a grą słów" (s. 41).

W dziedzinie etyki pragmatysta postuluje odrzucenie „bezwarunkowych i ponadkulturowych obowiązków moralnych zakorzenionych w niezmiennej, ahistorycznej naturze ludzkiej" (s. 31). To, że działamy „jako Ja”, nie powinno się przekształcać w złudzenie działania „zawsze dla Ja”. Trzeba odrzucić proste przeciwstawienie sobie altruizmu i egoizmu, które na przestrzeni wieków przyprawiało co wrażliwsze jednostki o ciagłe poczucie winy. Postęp 
moralny polega na uwzględnianiu potrzeb coraz większej liczby ludzi, a także coraz większej wrażliwości na cudzy ból i cierpienie. Pragmatyści nie szukaja uniwersalnej esencji człowieczeństwa, lecz staraja się opisać konkretne, obce nam grupy ludzi w taki sposób, aby drobne różnice między „nami” a „nimi” wydawały się stopniowo nieistotne.

$Z$ punktu widzenia polskiego czytelnika kontrowersyjna może się wydawać treść tekstu Religia jako ucinanie rozmowy. Rorty proponuje w nim, by wykluczyć ze sfery publicznej argumenty religijne, czyli odwołujące się do tzw. woli Bożej. W innym tekście, zatytułowanym Religion in the Public Sphere. A Reconsideration doprecyzowal, że nie chodzi mu o wprowadzanie zakazów prawnych, ale raczej o nacisk moralny, który doprowadziłby do traktowania odwołań do religii jako niemających zwiazku $z$ dyskusjami w sferze publicznej. Jako przykład podał powoływanie się przez amerykańskich fundamentalistów religijnych na Stary Testament $\mathrm{w}$ celu uzasadniania swojej nienawiści do gejów² ${ }^{2}$ Krótko mówiąc, autor Filozofii a nadziei na lepsze społeczeństwo twierdzi, że jak długo to możliwe, powinniśmy unikać powoływania się na autorytet papieża czy Pisma Świętego, aby uargumentować współobywatelom nasze przekonania. Jednocześnie ma nadzieję, że w przyszłości miejsce takich odwołań zajma argumenty ściśle utylitarne.

Innym elementem myśli Rorty'ego, który może budzić wątpliwości, jest przedstawiona przez niego w tekście Ścieżka pragmatysty: Umberto Eco o interpretacji koncepcja, która Andrzej Szahaj nazwał anarchizmem interpretacyjnym. Zgodnie $z$ nia interpretacja tekstu jest równoznaczna $z$ jego użyciem, umieszczeniem $w$ innym kontekście, w odniesieniu do innych tekstów. Interpretujący, zdaniem Rorty'ego, nie musi uwzględniać intencji autora, dokonując interpretacji jego dzieła, może też używać cudzego tekstu, całkowicie dowolnie w zależności od własnych potrzeb i celów. Koncepcja ta jest spójna $z$ całokształtem dorobku Rorty’ego, jednak kłóci się

2 R. Rorty: Religion in the Public Square. A Reconsideration, „Journal of Religious Ethics” 2003, t. 31, nr 1, s. 141-149. 
z intuicjami i oczekiwaniami przeciętnego odbiorcy literatury. Jak zauważa Andrzej Szahaj „[...] pozór "Obiektywności" [...] zachowywać będą w szczególności te interpretacje, które odwołują się do najbardziej elementarnej kompetencji kulturowej danej społeczności [...]. Dlatego też interpretacje odwołujące się do zdrowego rozsądku, wiedzy potocznej, czy też [...] wiedzy szkolnej, będa w szczególności nosić znamiona Obiektywności" ${ }^{3}$ - podkreśla Szahaj, prywatnie przyjaciel Rorty'ego i autor pierwszej poświęconej mu polskiej monografii. Interpretacje osobiste, idiosynkratyczne lub też wymagajace wysokich kompetencji kulturowych czy wiedzy ezoterycznej będa - przeciwnie - uznawane za bardziej subiektywne. Należy przy tym dodać, że to, które interpretacje okażą się obiektywne zależy $\mathrm{w}$ znacznym stopniu od istniejących $\mathrm{w}$ społeczeństwie stosunków władzy.

Trzeba jednak zaznaczyć, że tom Filozofia a nadzieja na lepsze społeczeństwo nie składa się jedynie $z$ rozważań metafilozoficznych. To także świetna, zawierająca jedynie elementy filozofii, uprawiana ze swada i subtelna ironia publicystyka polityczna. Dystans wobec samego siebie, swoich poglądów i zastanej rzeczywistości pozwala Rorty'emu na napisanie zdań, które w innym wypadku byłyby niestosowne. Przede wszystkim jest to jednak publicystyka pełna wiary $\mathrm{w}$ Amerykę. Neopragmatysta nie przyłącza się do chóru amerykańskich lewicowych, postmodernistycznych intelektualistów, którzy, jak pisze, „biora udział w konkursie "Ameryka jest do bani”". Stwierdza bowiem: „Sązę, że kraj ten, mimo swoich minionych i obecnych okropieństw i przywar [...] ucieleśnia najdoskonalszy $z$ wynalezionych dotychczas rodzajów społeczeństwa" (s. 52).

Sukces Rorty'ego w restytuowaniu amerykańskiej tradycji pragmatycznej niewattpliwie wynika $z$ tego, że jego romantyczny melioryzm odpowiadał stanowi świadomości amerykańskiej lewicy, zwłaszcza tej akademickiej, z końca XX wieku. Udało mu się z gracją wpleść w tok swoich wywodów wiele przeświadczeń oczywistych

${ }^{3}$ A. Szahaj: Granice anarchizmu interpretacyjnego, „Teksty Drugie” 1997, nr 6, s. 20. 
dla liberałów czy też progresywistów swej doby, choć nie całkiem oczywistych dla ludzi o odmiennych od niego poglacdach politycznych. Neopragmatysta składa zatem hołd amerykańskim związkowcom, pisząc: „Ruch związków zawodowych [...] okazał się najbardziej inspirująca inkarnacją chrześcijańskich cnót poświęcenia i braterskiej agape w udokumentowanej historii. Narodziny zwiąków zawodowych $z$ moralnego punktu stanowia najbardziej krzepiace zdarzenie współczesności, były one świadkiem najczystszego i najmniej egoistycznego heroizmu" (s. 265). Jednocześnie Rorty krytykuje rewolucyjny marksizm, a przede wszystkim jego elementy apokaliptyczne i deterministyczne, choć zarazem podkreśla: „Określenie historii, historią walki "klasowej" jest w dalszym ciagu prawdziwe, jeśli tylko rozumie się przez nie fakt, że przedstawiciele każdej kultury [...] jeśli tylko uda im się dojść do pieniędzy i władzy, będa kłamać oszukiwać i kraść, by upewnić się, że ich potomkowie zachowaja monopol na jedno i drugie" (s. 264).

Rorty rozumie jednak, że „motorem tego wielkiego nużącego potoku zwanego historia jest ekonomia" oraz że biednych nie stać „ani na miłość, ani komunikatywność". Przyznaje, że bardzo ubodzy ludzie z krajów Południa „przekraczaja nasza wyobraźnię” i moga ich ogarnąć jedynie „statystyki i poeci”. Zdaje sobie sprawę, że szanse na urzeczywistnienie globalnej, egalitarnej i demokratycznej wspólnoty sa nikłe. Mimo to kreśli utopijny obraz Stanów Zjednoczonych w 2096 roku, kiedy to obywatelom przyświeca ideał braterstwa, "stare związkowe hasło "krzywda jednego jest krzywda wszystkich" stanowi [...] slogan amerykańskiej polityki”, a „Piosenki Solidarity is Forever i This Land is Your Land spiewa się co najmniej tak często jak The Star-Spangled Banner" (s. 307).

Ameryka za sto lat jest w wizji Rorty'ego krajem, który wyzbył się ambicji mocarstwowych, w którym panuje powszechny konsens co do konieczności redystrybucji, a politycy powtarzają, że „nasza konsekwentnie niska produktywność to mała cena za zwiąkową kontrolę zakładów pracy i akcjonariat pracowniczy w większości firm” (s. 308). 
Rorty krytykuje amerykańska lewicę intelektualną za brak patriotyzmu, skutkujący politycznym kwietyzmem, i opowiada się za powrotem do „polityki klasowej” zamiast „polityki tożsamości”. Często jednak pozwala sobie na retoryczna przesadę, na przykład kiedy pisze, że "Celem Ameryki było pierwsze bezklasowe społeczeństwo na świecie" lub gdy porównuje Manifest komunistyczny z Nowym Testamentem, dodając jednocześnie, że obydwa powinniśmy traktować jako dokumenty inspirujace, jako odwołania do tego, co Lincoln nazwał „lepsza strona naszej natury”, nie zaś jako trafne ujęcia ludzkiej historii bądź ludzkiego przeznaczenia.

Chyba jednak żaden egalitarysta i postępowiec nie odmówi Rorty'emu racji, gdy ten, zwracając się do amerykańskiej lewicy intelektualnej, podkreśla: „Powinniśmy wychować nasze dzieci w takim duchu, by uznawały za rzecz niedopuszczalna, że my, ludzie schowani za biurkami, zarabiamy dziesięciokrotnie więcej od osób brudzących sobie ręce czyszczeniem toalet i stokrotnie więcej od tych składajacych nasze klawiatury w krajach Trzeciego Świata. [...] Nasze dzieci musza od wczesnych lat nauczyć się postrzegać nierówności dzielące ich położenie od położenia innych dzieci nie jako rezultat woli Bożej czy też nieunikniony koszt efektywności gospodarczej, ale jako tragedię możliwą do uniknięcia" (s. 261-262).

Niewatpliwie faktem jest, że Rorty wykorzystał autorytet, który budował sobie podczas tradycyjnej kariery akademickiej, aby wpleść w swoją filozofię lewicowe przekonania i intuicje moralne charakterystyczne dla znacznej części amerykańskiej profesury. Nie sposób jednak przy tym odmówić mu wdzięku i uwodzicielskiego uroku.

Tomasz Sosnowski

Tomasz Sosnowski - doktorant w Zakładzie Filozofii Polityki Instytutu Filozofii Uniwersytetu Warszawskiego. 